Problems of World Agriculture volume 18 (XXXIII), number 4, 2018: 250-258 DOI: 10.22630/PRS.2018.18.4.115

Anna M. Klepacka ${ }^{1}$

Warsaw University of Life Sciences - SGGW, Poland

\title{
Sustainable Development and Renewable Energy Sectors: Selected Indicators in European Union and Poland
}

\begin{abstract}
The aim of this article was to show the position of Poland in the renewable energy subsectors among the European Union countries. The research covered the areas of biomass, solar heating and heat pumps, showing the degree of their utilization, power required to drive the system and their production in 2016. The provided information was supplemented with a revenue per employee in thousand euros in chosen subsectors of renewable energy sources in the year 2016. The main tool for carrying out the set objective was the use of descriptive and comparative methods. The results of the survey demonstrated Poland's prominent place in the sector of liquid biofuels $\left(1^{\text {st }}\right.$ place in EU), thanks to the significant supply of raw materials as well as development perspectives in solar energy, which is confirmed by the world's statistics indicating a record number of photovoltaic installations fitted (PV).
\end{abstract}

Key words: Sustainable development, renewable energy, UE, Poland

JEL Classification: Q56, Q20, Q42

\section{Introduction}

The increased environmental and social awareness resulted in the formation of the concept of sustainable development, which is a core element in the development strategy at the global and local levels (Baum, 2011). According to Majewski (2008), the idea "act local - think global" points out that actions undertaken by individuals and organizations with a view to satisfying their individual needs and the implementation of individual goals add up to a set of positive and negative effects on a global scale. The starting point for the awareness and the acknowledgement of "the responsibility as a global citizen" for the present and future state of the natural environment and prosperity for the next generations is the accumulation of negative effects of human activity. According to Klank (2005) the integration of problems concerning the economic growth and environmental protection made the concept of sustainable development the most important strategy of the world's lasting development. The 2030 Agenda for Sustainable Development (Agenda Post-2015) replaced Millennium Development Goals adopted in 2000 and is currently the World National Development Plan (https://sustainabledevelopment.un.org/sdg7). The seventh goal of the Agenda, among the total of seventeen goals, is ensuring a universal access to affordable, reliable, sustainable and modern energy. Energy is indispensable for every daily activity in the modern world. The energy in the sustainable development encompasses employment, security, climate change, food production and income (https://www.un.org/sustainabledevelopment/energy). Global Recommendations include wider access to clean energy and progress regarding the integration of renewable energy into end-use applications in construction, transport and industry. Furthermore, an increase of

\footnotetext{
1 PhD, Faculty of Production Engineering WULS - SGGW, 164 Nowoursynowska St., 02-787 Warsaw,
} e-mail: anna_klepacka@sggw.pl; https://orcid.org/0000-0002-2828-5429 
public and private investment in the renewable energy is crucial as are the regulatory framework and innovative business models if the goal is to transform the world's energy systems.

Renewable energy technologies are recognized essential for the implementation of the Agenda goals, which, apart from the widely understood environmental protection and the increase in energy security, involve stimulating economic development by creating new industries and new jobs (REN21, 2018). The renewable energy industry created in excess of 500,000 new jobs globally in 2017, and the total number of the employed in the sector stood at 10.3 million (a 5.3\% increase from 2016). For example, among various technologies based on renewable energy sources was the solar photovoltaic (PV) sector that was the largest employer where the number of new jobs increased by $9 \%$ (3.4 million jobs globally in 2017) following a record $94 \mathrm{GW}$ of installations in 2017 (IRENE, 2018). The PV installations experienced growth in Poland in 2017 after the government modified the regulations guiding the private investment permitting household-level investment.

The European Union (EU) has adopted a series of regulatory measures to promote renewable energy sources on the basis of The Directive 2009/28/EC (Dz. U. UE L 09.140.16), which designated for Poland the share of RES energy in the national energy balance not less than $15 \%$ by 2020 . As recently as in June 2018, the European Commission, the European Parliament and the Council of the EU agreed upon a new Renewable Energy Directive. The binding target of $32 \%$ from renewables was set by 2030 with the necessity for periodic inspection of the goal implementation and the possibility of increasing it. It means that within the next 12 years more than $1 / 3$ of energy in the EU will be produced by wind farms, photovoltaic panels, hydropower plants and other installations, which do not burn fossil fuels. Furthermore, the goal of RES share in the transportation sector amounts to $14 \%$ assuming the reduction in the use of first-generation biofuels and imported biofuels, primarily biodiesel obtained from the palm oil. A larger role of prosumers, that is the renewable energy utilizing installations of up to $25 \mathrm{~kW}$, was also assumed. The adopted changes will substantially contribute to the EU world leadership in developing renewable energy technologies. It will also enable the EU to maintain its principal position in the struggle against climate change, clean energy transformation and achievement of the goals sets in Paris Agreement (https://energetyka.wnp.pl/uwaga-uzgodniono-nowe-cele-oze-narok2030, 325063_1_0_0.html).

\section{Material and methods}

The aim of the current study was the comparison of selected measures characterizing renewable energy sectors in Poland and the major renewable energy EU producing-countries. The comparisons involve the growth of RE sectors between 2016 and 2017. This study included the following indicators, the installed capacity, power generation, the level of employment as well as energy production and revenues in five sectors of renewable energy. The selection of the five sectors was guided by their relevance given the natural resource endowment (biofuels, wind energy, heat pumps) or recent modifications in regulations pertaining to the renewable energy utilization (thermal solar energy use and PV installations) in Poland. Both the natural conditions and regulations are key determinants for the economic importance of renewable energy sectors and their influence on power generation, job creation, and the revenue stream. The information was extracted from the literature on the subject, while the data were obtained from international and domestic sources, including 
EurObserv'ER, Główny Urząd Statystyczny (GUS) and Eurostat. The main tool for carrying out the set objective was the application of descriptive and comparative methods. The choice of the year 2016 was conditioned by the availability of the data allowing the comparison of chosen renewable energy sources that are the subject of this study.

\section{Results and discussion}

On the basis of the GUS (2018), Poland took 6th place in primary energy acquisition as compared to EU countries in 2016. In the structure of primary energy the shares of various renewable energy sources in the EU (in Poland) ranged from about $5 \%$ to nearly $45 \%$ ( $0.2 \%$ to almost $71 \%$ in Poland): solid biofuels $44.7 \%$ (70.7\%), hydropower $14.3 \%$ $(2.0 \%)$, wind power $12.4 \%(11.9 \%)$, biogas $7.9 \%(2.9 \%)$, liquid biofuels $6.5 \%(10.2 \%)$, solar energy $6.3 \%(0.7 \%)$, municipal waste $4.7 \%(0.9 \%)$, geothermal energy $4.7 \%(0.2 \%)$ and heat pumps $0.6 \%$ in Poland. In the case of electricity production, Poland placed 7 th in the EU in 2016. However, in the EU the share of renewable energy in the gross energy consumption was $17 \%$, while $11.3 \%$ in Poland reflecting an almost double increase between 2004, the year of the accession of Poland to the EU, and 2016 (Siudek and Klepacka, 2018). The increase in the share in the EU in 2016 as compared to 2004, shows a growing tendency of the share of renewable energy in electricity generation, $29.6 \%$ (in Poland the increase was almost threefold and amounted to $13.4 \%$ ), the share of renewable energy in transport was $7.1 \%$ (3.9\% in Poland), and the share of renewable energy in the heating and cooling amounted to $19.1 \%$ (14.7\% in Poland) (GUS, 2018).

\section{Solid biofuels}

Biofuels include non-fossil substances of biological origin, which may be used to produce heat or generate electric energy (GUS, 2016). These include: wood, wood chips, forestry residue (e.g. tree branches), waste generated in the wood processing industry (e.g. sawdust), straw (waste from agricultural production), crops of energy plants as well as briquettes and pellets (refined fuels) (Sadlok 2014). In 2016, the national energy consumption generated from solid biomass amounted to 98.4 Mtoe (a 3.0 Mtoe increase as compared to 2015 in the $28 \mathrm{EU}$ member-states), whereas (an increase of $3.1 \mathrm{Mtoe}$ ) the estimated use of solid biofuels in primary energy production was 95.0 Mtoe. The gap between consumption and production was covered mainly by the wood pellet imports from the USA, Canada and Ukraine. Germany was the leader in the largest production combined with the most efficient use of primary energy production from solid biomass estimated at 12.2 Mtoe (12.8\% of total production), followed by France, 11.1 Mtoe $(11.7 \%)$ and Sweden, 9.4 Mtoe (9.9\%). Poland placed sixth among the EU countries with the production of 6.4 Mtoe and the use amounting to 6.6 Mteo (EurObserv'ER, 2017a and 2017b).

Poland has suitable natural conditions for the production of solid biofuels including agricultural feedstock (Gradziuk et al., 2003) and wood biomass (Klepacka, 2018). Additionally, the share of forested area steadily increased in Poland in recent decades suggesting an increase supply of wood biomass in the future. The large share of grains in the crop area in Poland also may permit a larger use of biomass in generating energy from renewable energy. Overall, Poland may have a relative comparative advantage on the utilization of solid biomass suggesting its lasting role consistent with sustainable development. 


\section{Wind energy}

Wind, next to solid biofuels, is historically one of the oldest energy sources, and its potential, together with technological advances, has been increasing. Technologies used in wind energy installations transform wind power (the air flow speed) into electricity. Despite technological advances reducing the efficiency barriers, the rate of installed wind power capacity still depends on local wind patterns. By the end of 2016, the installed amount of wind-based power capacity in the EU wind energy installations was $154.4 \mathrm{GW}$, which constituted a value higher than in 2015. Among the top EU member-countries Germany had the largest installed capacity of $49.6 \mathrm{GW}(32.1 \%$ of total UE capacity), followed by Spain, $23.3 \mathrm{GW}$ (15.1\%), and Great Britain, $11.5 \mathrm{GW}$ (7.4\%). Poland occupied 7 th place with the capacity reaching $5.7 \mathrm{GW}(3.7 \%)$, that is about $0.8 \mathrm{GW}$ higher than in 2015. However, in the UE wind energy production increased by 1 TWh in 2016 as compared to 2015, accounting for a combined total capacity of $302.9 \mathrm{TWh}$. Considering the growth of the installed generation capacity, there was a slight difference in the production as compared to 2015. The installed capacity in Germany, Spain and Great Britain allowed the production of $78.6 \mathrm{TWh}(26.0 \%$ of total production electric energy in the UE), 48.9 TWh (16.1\%) and 37.4 TWh (12.3\%), respectively. In Poland, windmills generated 12.6 TWh $(4.2 \%)$ of energy placing the country $8^{\text {th }}$ in the EU (EurObserv'ER 2017a and 2017c).

In the near future the use of wind energy will be determined by the wind farms located offshore in the Baltic Sea. The planned large wind farm near Łeba demonstrates the involvement of the government in this type of renewable energy utilization. The change in regulations guiding the RE industry introduced in 2017 put the wind energy installations on agricultural land at a relative disadvantage by imposing a minimum distance between a windmill and the nearest residence. Additionally, the prevailing wind patterns in Poland do not favor windmill location in some regions, while making the location along the sea coast particularly well suited. The lasting contribution of wind energy to sustainable development is constrained by the possible intermittent and unpredictable occurrence of winds.

\section{Liquid biofuels}

Liquid biofuels constitute a category of fuels, which include fuels manufactured with natural raw materials (biomass or biodegradable fraction of waste), which are mainly used in transport (GUS 2016). In 2016 the consumption of liquid biofuels was at the level of 14.2 ktoe in the EU; $79.8 \%$ (11.4 ktoe) constituted biodiesel and 19.1\% bioethanol (2.7 ktoe). The slight increase in the bioethanol share in renewable energy in the transportation sector, amounting 1 toe, was noted as compared to 2015. The largest shares in the global consumption of biofuels have France, 3.1 ktoe $(21.8 \%)$ Germany, 2.6 ktoe $(18.3 \%)$, and Sweden, 1.5 ktoe $(10.6 \%)$. Poland held $8^{\text {th }}$ placed in the EU with the amount of 0.5 ktoe (3.5\%) (EurObserv'ER 2017a and 2017d). The EU member-countries' national policies promoting renewable energy and energy efficiency in the transportation sector concentrate on the road transport, and involve biofuels, electromobility and fuel efficiency. The use of biofuels for transport is blocked by the EU laws and provisions concerning the use of conventional biofuels and slow technological progress in the advanced fuel production (REN21, 2018).

Poland is competitive in the production of biodiesel from rapeseed oil. In recent years, as much as one-half of the annual rapeseed crop was pressed for oil used in biodiesel manufacturing. The ban on palm oil imports to the EU by 2021, the relative competitive position of Polish rapeseed farmers may improve despite the limit on the overall share of 
biodiesel in the use of biofuels used in road transportation. It is also possible, that due to technological progress, new manufacturing process will enable the lasting role in the renewable energy generation and its contribution to sustainable development.

\section{Solar energy}

The energy of solar radiation can be used in the systems allowing heat production (solar collectors) or electricity (photovoltaic cells) (Ginialski, 2013). Despite its enormous potential, solar energy has also disadvantages. The biggest one is the changing of solar radiation intensity not only during a day but also throughout the whole year. The energy consumption planning is hampered by the lack of predictability. The energy sector using solar energy, however, is growing (Różycki, 2015). In 2016, the total power of the solar collectors installed in the EU amounted to $35.3 \mathrm{GWth}$ and it was higher by $1.2 \mathrm{GW}$ th than in 2015. The biggest share in the EU installed power had collectors installed in Germany (13.4 GWth), Austria (3.6 GWth) and Greece (3.1 GWth). In Poland, the installed capacity amounted to $1.5 \mathrm{GWth}$, placing the country 7 th among the EU member-countries. The development of the heat production market which makes use of solar energy, however, is under pressure from low prices of natural gas and heating oil, which significantly affect the competitive position of solar heat. Additionally, relatively high interest in the photovoltaic panels observed among house owners and investors contributes to the slower development of solar heat energy sub-sector (EurObserv'ER, 2017a and 2017e).

In 2016, the total installed capacity in the photovoltaic sector in the EU amounted to $100.8 \mathrm{GW}$, a growth of more than $6.1 \mathrm{GW}$ as compared to 2015. The largest installed capacity was in Germany, 40.7 GW, Italy, $19.3 \mathrm{GW}$ and Great Britain 11.9 GW. In total, the installed power of photovoltaic cells in the above mentioned countries constituted $71.3 \%$ of the total EU power. As for the EU, total electricity generation was $105.2 \mathrm{TWh}$ (a $2.8 \%$ growth as compared to 2015 ), $67.1 \%$ of which was produced, among others, in the already two leading countries in terms of the installed capacity, that is Germany $38.1 \mathrm{TWh}$, Italy 22.1 TWh and Great Britain 10.4 TWh, respectively (2017f). In Poland the installed power amounted to $0.2 \mathrm{GW}$ (18th place in the EU), which allowed electricity generation on the level of 0.1 TWh (21st place) (EurObserv'ER, 2017a and 2017f).

The modified regulations governing the renewable energy utilization in 2017 placed the commercial solar power plants at the relative disadvantage with regard to microinstallations by homeowners. The patterns of solar radiation in Poland do not favor all regions as areas suitable for the installations of solar energy utilizing equipment. However, the clean solar energy will continue to make contribution to renewable energy use replacing, at least to some extent, the dependence on fossil fuels, especially coal, a desired effect consistent with the strategy of sustainable development.

\section{Heat pumps}

Systems using heat pumps exploit temperature differences to generate energy. The geothermal energy converted into the heat energy is then used for heating or cooling utility rooms as well as for heating usable water (PORTPC, 2015). Heat pumps can be used only for heating, however, if they are reversible, they can divert the heat present in the building in order to cool it. In 2016 there were 32.0 million heat pumps working in the EU, which implies a growth of 2.4 million as compared to 2015. The largest number of heat pumps was installed in Italy (19.1 million), France (5.2 million) and Spain (2.3 million). Poland, when compared to other EU countries, placed 16th, with the number of pumps estimated at 0.09 million (growth by 0.03 million heat pumps, or 50\% more as compared to 2015). In 
2016, 9.8 Mtoe of energy was produced, comparing to 9.1 Mtoe in 2015 (an increase by 7.8\%) (EurObserv'ER, 2017a).

The natural conditions in Poland permit the use of heat pumps utilizing the temperature of various media. Their use is limited by the cost of the equipment given the current level of per capita income. The major advantage of geothermal heat pumps is their independence from the weather conditions, especially when compared to wind or solar energy. The recently adopted regulations regarding the construction of new buildings are likely to increase the heat pump installations making a lasting contribution to the country's sustainable development.

\section{Employment and revenues in the sector of the chosen renewable energy sources}

The sector of solid biofuels is the renewable energy sector, which generates the highest number of jobs in the EU. It was estimated that, in 2016, the employment in the renewable energy utilization was responsible for $352.5 \mathrm{~K}$ jobs (an increase by $6.4 \mathrm{~K}$ as compared to 2015). The revenues in the industry amounted to $€ 31.9$ billion and were higher by $€ 0.9$ billion than in 2015. Germany was the European leader not only in the production and utilization of primal energy from solid biofuels, but also in terms of employment with $42.5 \mathrm{~K}$ jobs (12.1\% of the total EU employment) and revenues equal $€ 5.1$ billion $(16.0 \%$ of EU revenues). The French solid biofuels market generated $35.4 \mathrm{~K}$ jobs (2nd place when compared to other member countries), and the revenues was estimated to $€ 4.1$ billion ( $3 \mathrm{rd}$ position). In terms of employment rate, Italy placed 3rd with $32.6 \mathrm{~K}$ jobs, generating national revenues of $€ 2.5$ billion in this sector (5th place). Poland and Finland were the two remaining countries among the top EU member-countries when analyzing employment in the solid biofuels sector. The Polish sector of solid biomass constituted $26.1 \mathrm{~K}$ employees (4th position) and the revenues of $€ 1.0$ billion (9th position), while Finland reported $25.4 \mathrm{~K}$ jobs (5th place) and $€ 4.3$ billion in revenues (2nd place), respectively. All above mentioned countries represented $46.0 \%$ of the total employment in the analyzed sector in the EU (EurObserv'ER, 2017a and 2017b). The European sector of solid biofuels is internationally competitive. The share of the solid biofuels is to increase thanks to a well-balanced usage and the development of the agroforestry (EurObserv'ER, 2017a).

The sector of wind energy contributes substantially to the European power generation. While the revenues in 2016 was estimated at $€ 39.3$ billion, the employment amounted to 309.0 $\mathrm{K}$ jobs. The German wind energy sector was the European leader with $121.7 \mathrm{~K}$ jobs and the turnover of $€ 16.0$ billion and represented $39.4 \%$ of the total EU wind energy sector employment. The second place was taken by Great Britain with $42.9 \mathrm{~K}$ jobs, which constituted $13.9 \%$ of the EU employment, and the revenues amounting to $€ 4.5$ billion. Denmark occupied the next place with its jobs of $26.6 \mathrm{~K}$ people and the revenues of $€ 4.6$ billion. In Poland, in the sectors connected with wind energy, there were $11.4 \mathrm{~K}$ jobs ( 7 th place in the EU), and the revenues was estimated at $€ 0.8$ billion (9th place) (EurObserv'ER, 2017a and 2017c).

The employment in the EU sectors connected with the liquid biofuels was estimated to $205.1 \mathrm{~K}$ jobs (an increase of $26.9 \mathrm{~K}$ as compared to 2015), whereas the revenues was at the level of $€ 13.1$ billion (a growth of $€ 1.4$ billion) in 2016 . One should note that, in the case of the solid biofuels, the estimated employment and revenues include the activities connected with the supply of raw materials, especially agriculture. Thus, the leading countries were not necessarily the biggest biofuels consumers. They were just the member countries with the big share of agricultural area. As a result of the significant raw material supply and biomass exports, Poland reached the 1st place in the sector employment within the EU, 
with the estimated $34.8 \mathrm{~K}$ jobs and the revenues of $€ 1.3$ billion (3rd place). France, as a leading biofuels consumer in the $\mathrm{EU}$, in the sectors connected with their production employed $33.2 \mathrm{~K}$ people (2nd place in the EU) and the national industry generated revenues of $€ 3.2$ billion (1st place) in 2016. Despite insignificant use of liquid biofuels in Romania $(0.3 \mathrm{Ktoe})$ and a few new installations, operation and maintenance (revenues of $€ 0.8$ billion), this country placed $3 \mathrm{rd}$ as far as the employment is concerned with $23.8 \mathrm{~K}$ jobs, which resulted from its agricultural character. In Germany the employment rate was estimated to $21.8 \mathrm{~K}$ jobs (4th position in the EU) and $€ 2.3$ billion of revenues (1st in the EU) (EurObserv'ER, 2017a and 2017d).

Table 1. Turnover per employee thousands of euro in RES subsectors and in leading EU countries in 2016

\begin{tabular}{|c|c|c|c|c|c|c|}
\hline \multirow{3}{*}{ Selected EU countries } & \multicolumn{6}{|c|}{ Selected of renewable energy subsectors } \\
\hline & $\begin{array}{c}\text { Solid } \\
\text { biofuels }\end{array}$ & Wind energy & $\begin{array}{c}\text { Liquid } \\
\text { biofuels }\end{array}$ & $\begin{array}{l}\text { Solar energy } \\
\text { Collectors CSP }\end{array}$ & $\begin{array}{l}\text { Solar energy } \\
\text { PV cells }\end{array}$ & Heat pumps \\
\hline & \multicolumn{6}{|c|}{ Turnover per employee, thousands of euro } \\
\hline EU & 127,02 & 90,61 & 63,92 & 116,55 & 111,89 & 121,09 \\
\hline Denmark & 172,93 & 170,59 & 150,00 & $\underline{165,63}$ & 166,67 & 161,90 \\
\hline Finland & 148,57 & 170,08 & 103,45 & - & $\underline{200,00}$ & 155,56 \\
\hline France & 148,40 & 115,54 & 95,47 & 136,36 & 136,54 & 141,16 \\
\hline Germany & 131,96 & 120,24 & 105,50 & 118,75 & 125,46 & 132,41 \\
\hline Greece & 81,08 & 44,12 & 33,33 & 73,33 & 81,82 & 78,57 \\
\hline Ireland & 104,76 & 117,65 & - & 100,00 & - & 100,00 \\
\hline Italy & 150,79 & 77,91 & 96,92 & 121,43 & 130,84 & 130,64 \\
\hline Netherlands & 122,37 & 123,08 & $\underline{175,00}$ & 100,00 & 119,15 & 125,00 \\
\hline Poland & 69,30 & 38,70 & 37,64 & 63,64 & 60,00 & 63,64 \\
\hline Portugal & 78,13 & 89,23 & 50,00 & 50,00 & 57,14 & 59,46 \\
\hline Spain & 120,00 & 41,85 & 59,60 & 122,50 & 100,00 & 95,39 \\
\hline Sweden & $\underline{206,12}$ & $\underline{218,72}$ & 43,42 & - & $\underline{200,00}$ & $\underline{202,88}$ \\
\hline United Kingdom & 104,66 & 86,51 & 82,22 & 50,00 & 96,90 & 94,44 \\
\hline
\end{tabular}

Note: In case of employment: no calculations were made for Sweden - in the solar collector sector, Ireland -liquid biofuels and PV cells due to the lack of precise data (according to source $>1$ ).

Source: Author's own study based on EurObservER 2017a.

Employment and revenues levels in the range of solar collectors also include Concentrated Solar Power technologies (CSP), which are applied only in few European countries (primarily in Spain). In 2016 the total employment in these sectors in EU was estimated to $29.0 \mathrm{~K}$ jobs (a decrease by $6.0 \%$ from 2015), and revenues to $€ 3.4$ billion $(1.0 \%$ less than in 2015). The highest figures were recorded in Spain ( $8.0 \mathrm{~K}$ employees and $€ 1.0$ billion, respectively), Germany (6.4 K employees and $€ 0.8$ billion), and Denmark (3.2 $\mathrm{K}$ employees and $€ 0.5$ billion). It is worth mentioning that, among the top European countries, only Denmark registered growth of employment and the revenues in 2016 as compared to 2015. When compared to the EU, Poland was a country in which one of the most significant changes was recorded in the 2015/2016 period. The employment rate decreased by one half, from $2.2 \mathrm{~K}$ to $1.1 \mathrm{~K}$ (8th in $\mathrm{EU}$ ) and the revenues dropped from $€ 0.13$ billion to $€ 0.07$ billion (also 8th place). The decrease of subsidies, low natural gas prices and increased interest in heat pumps as well as in photovoltaic panels can be responsible for such a situation (EurObserv'ER, 2017a and 2017e). 
In 2016, the European PV sector represented a $€ 10.7$ billion value (as compared to the $€ 12.7$ billion in 2015) and employed $95.9 \mathrm{~K}$ (a decrease from $113,4 \mathrm{~K}$ in 2015). As far as the employment is concerned, the leading countries were Great Britain, $29.0 \mathrm{~K}$ jobs $(30.2 \%$ of the total EU employment in this sector), Germany, $27.1 \mathrm{~K}(28.3 \%)$ and Italy, $10.7 \mathrm{~K}$ (11.2\%). Germany ( $€ 3.4$ billion), Great Britain ( $€ 2.8$ billion) and Italy ( $€ 1.4$ billion) had the highest revenues. In Poland, the employment in the PV subsector amounted to $1.5 \mathrm{~K}$ jobs (11th place in the EU) and the market generated the income of $€ 0.14$ billion (13th place) (EurObserv'ER, 2017a and 2017f).

In 2016, the total employment connected with the heat pump sector of renewable energy in the EU was estimated to $249.4 \mathrm{~K}$ jobs as compared to $240.3 \mathrm{~K}$ in 2015 and the revenues estimated at $€ 30.2$ billion ( $€ 29.6$ billion in 2015). The highest number of jobs and the highest revenues among all EU member-countries was recorded in Italy $(94.0 \mathrm{~K}$ jobs and $€ 12.3$ billion), Spain (60.8 K jobs and $€ 5.8$ billion) and France (32.8 K jobs and $€ 4.6$ billion). In Poland the total employment in the discussed sector was estimated at $2.2 \mathrm{~K}$ jobs (10th place in the EU) and the revenues of $€ 0.14$ billion (13th place) (EurObserv’ER, 2017a).

Table 1 presents the turnover per employee in $€$ thousands in the chosen sectors of RES and in leading EU countries, in terms of their development.

In 2016, at the EU level, the employment in the Renewable Energy Sources sectors was estimated at 1.1 million jobs. The largest number of job a generated by RES sectors was in Germany $(234.0 \mathrm{~K})$. In Poland, there were $77.1 \mathrm{~K}$ people employed in RES sectors. According to the figures shown in Table 1, the highest level of revenues per employee in $€$ thousands in the selected RES sectors was in the sectors associated with the solid biofuels $(€ 127.02 \mathrm{~K})$, heat pumps (€121.09 K) and solar energy, CSP collectors (€116.65 K). The highest revenues per employee in RES subsectors was recorded in the subsector of solid biofuels (€206.12 K), wind energy (€218.17 K), heat pump (€202.88 K) in Sweden, and solar energy, PV cells ( $€ 200.00 \mathrm{~K}$ ) ex aequo in Sweden and Finland. In the case of the liquid biofuel sector the highest level of the revenue per employee was recorded in the Netherlands ( $€ 175.00 \mathrm{~K})$. Poland, in comparison with the analyzed EU countries, reached the highest position in the solar energy sector, solar collectors (€63.64 K).

\section{Concluding remarks}

Focusing on the increased energy efficiency and the use of renewable energy sources is of a key importance in terms of their lasting contribution to sustainable development. The increase of the share of the energy from renewable sources in the EU involves the creation of new jobs, which positively affects the economic growth. Moreover, with each newly employed person in the RES sector higher revenues are generated, which should affect the level of income at the international, national and local levels. In Poland, the position of the renewable energy sources have a real chance for growth in the foreseeable future thanks to the stable regulations, which create mechanisms allowing to shorten the investment pay-back period of the secure financial returns. Within a decade, Poland stands a chance to become a significant market for RES utilization, already indicated by its 1st position in the level of employment in the liquid fuels sector, the substantial supply of raw materials, and exports when compared to other EU countries as well as the level of employment in the PV sector, with the record number of assembled PV installations confirmed by international statistics (IRENE, 2018). 


\section{Literature}

Baum, R. (2011). Ocena zrównoważonego rozwoju w rolnictwie (studium metodyczne) (Evaluation of sustainable development in agriculture (methodological study). Rozprawy Naukowe 434. Wyd. UP w Poznaniu.

Ciepiela, D. (2018). Uwaga! Uzgodniono nowe cele OZE na rok 2030 (Attention! New RES targets for 2030 were agreed). Downloaded October 10, 2018 from: https://energetyka.wnp.pl/uwaga-uzgodniono-nowe-cele-ozena-rok 2030,325063_1_0_0.html.

Dyrektywa Parlamentu Europejskiego i Rady 2009/28/WE z dnia 23 kwietnia 2009 r. w sprawie promowania stosowania energii ze źródet odnawialnych zmieniajaca $i$ w nastęstwie uchylająca dyrektywy 2001/77/WE oraz 2003/30/WE (Directive 2009/28/EC of the European Parliament and of the Council of 23 April 2009 on the romotion of the use of energy from renewable sources and amending and subsequently repealing Directives 2001/77/EC and 2003/30/EC). Dz.U. UE L 09.140.16.

EurObserv'ER. 2017a. The state of renewable energies in Europe. EDITION 2017. 17th EurObserv'ER Report. Downloaded October 10, 2018 from: https:/www.isi.fraunhofer.de/content/dam/isi/dokumente/ccx/2018/ EurObservER-Annual-Overview-2017-EN-1.pdf

EurObserv'ER. 2017b. Solid biomass barometer. Downloaded: https://www.eurobserv-er.org/category/barometer-2017/.

EurObserv'ER. 2017c. Wind energy barometer. Downloaded: https://www.eurobserv-er.org/category/barometer-2017/.

EurObserv'ER. 2017d. Biofuels barometer. Downloaded: https://www.eurobserv-er.org/category/barometer-2017/.

EurObserv'ER. 2017e. Solar thermal and concentrated solar power barometer. Downloaded: https://www.eurobserver.org/category/barometer-2017/.

EurObserv'ER. 2017f. Photovoltaic barometer. Downloaded: https://www.eurobserv-er.org/category/barometer-2017/.

Eurostat (2018). Renewable energy statistics. Downloaded 10 October 2018 from: https://ec.europa.eu/ eurostat/statistics-explained/index.php/Renewable_energy_statistics.

Ginialski, Z. (2013). Odnawialne źródła energii w gospodarstwach rolnych (Renewable energy sources on farms). Radom: CDR w Brwinowie.

Główny Urząd Statystyczny (GUS) (2016). Zasady metodyczne badań statystycznych z zakresu energii ze źródeł odnawialnych (Methodical principles of statistical surveys in the field of renewable energy). Warszawa.

Główny Urząd Statystyczny (GUS). 2018. Energia 2018 (Energy 2018). Warszawa.

Gradziuk, P., Grzybek, A., Kowalczyk, K., Kościk, B. (2003). Biopaliwa (Biofuels). Wyd. Wieś Jutra, Warszawa.

International Renewable Energy Agency (IRENE) (2018). Renewable Energy and Jobs. Annual Review 2018.

Klank, L. (2005). Rozwój zrównoważony obszarów wiejskich; przegląd teorii (Sustainable development of rural areas; theory review). Maszynopis KEiOGR SGGW. Warszawa.

Klepacka, A.M. (2018). Potencjał użytkowy pelletu z biomasy drzewnej: energia odnawialna jako element zrównoważonego rozwoju (The potential of pellet made from wood biomass: renewable energy as a sustainable development element). Roczniki Naukowe SERiA, 20(6), 124-132.

Majewski, E. (2008). Trwały rozwój i trwałe rolnictwo - teoria a praktyka gospodarstw rolniczych (Sustainable development and sustainable agriculture - theory and practice of farms. Wyd. SGGW.

Polska Organizacja Rozwoju Technologii Pomp Ciepła (PORTPC) (2015). Poradnik inwestora - Energia geotermalna i pompy ciepła. Informacje i porady dla poczatkujacych (Investor's guide - Geothermal energy and heat pumps. Information and tips for beginners).

REN21 (2018). Renewables 2018 Global Status Report.

Różycki, K. (2015). Możliwości wykorzystania energii promieniowania słonecznego w budynku w polskich warunkach klimatycznych (Possibilities of using solar energy in a building in Polish climatic conditions). Polska Energetyka Stoneczna, 1, 27-34.

Sadlok, R. (red.) (2014). Przeciwdziałanie niskiej emisji na terenach zwartej zabudowy mieszkalnej (Preventing low emissions in areas of compact residential buildings). Bochnia: Stowarzyszenie na rzecz efektywności energetycznej i rozwoju odnawialnych źródeł energii „HELIOS”, Bochnia.

Siudek, A., Klepacka, A.M. (2018). Reduction of CO2 emissions and growth in the use of microinstallations of renewable resources in rural areas. Roczniki Naukowe SERiA, 20(5), 193-199.

Sustainable Development Goals. Downloaded 10 October 2018 from: https:/www.un.org/sustainable development/energy/.

Sustainable Development Goals. Downloaded 10 October 2018 from: https://sustainabledevelopment.un.org/sdg7.

Wind Europe (2017). Wind energy in Europe: Outlook to 2020.

For citation:

Klepacka A.M. (2018). Sustainable Development and Renewable Energy Sectors: Selected Indicators in European Union and Poland. Problems of World Agriculture, 18(4), 250-258;

DOI: 10.22630/PRS.2018.18.4.115 